\title{
Prevalence of Blood Parasites In Tyrannidae (Flycatchers) in the Eastern Plains of Colombia
}

\section{Nubia E Matta/ ${ }^{+}$, Natalia Basto, Rafael Gutierrez, 0 scar A Rodríguez, Ellis C Greiner*}

\author{
Departamento de Biología, Universidad Nacional de Colombia, Ciudad Universitaria, Bogotá, Colombia \\ *Department of Pathobiology, University of Florida, Gainesville, FL, US
}

Blood samples from 159 birds of the New-world family Tyrannidae (the flycatchers) from the eastern plains of Colombia, were examined for haematozoa parasites, in 1999-2000. Haematozoa were detected in six of 20 species. The overall prevalence was $10.1 \%$. The most common parasites detected were microfilariae, followed by Trypanosoma and Plasmodium. The highest prevalence (9.6\%) was found in the Ochre-bellied Flycatcher (Mionectes oleaginea). Mixed infections with more than one genus of blood parasite were rare and most infections encountered were of low intensity. The results of this study suggest an important role of ecologically diverse conditions determining composition, transmission, and prevalence of a blood parasite fauna, presumably through host interaction population density. Some new host parasite relationship records are presented.

Key words: Haematozoa -Tyrannidae - flycatchers - blood parasites - Neotropical region

The neotropical avifauna inhabits the most extensive and luxuriant rainforest in the world as well as a wide range of habitats of the lowland and mountains, and comprises approximately 3300 species. Flycatchers are primarily insectivorous birds, adapted to open or terrestrial environments (Haffer 1985). The distribution of the 377 species of Tyrannidae is mainly confined to the Neotropical region with a few species extending northwards through Central America to the Nearctic.

Despite this wide distribution, data of blood parasites of this family are, with a few exceptions, scarce. In the western hemisphere there have been two major avian haemoparasite surveys, i.e. Greiner et al. (1975) for North America and White et al. (1978) for the Neotropical Region. Among the 57,026 North American birds for which data were available, the examined Tyrannidae composed only $0.5 \%$. Among the 35,555 Neotropical birds the tyraniids composed only $3.5 \%$. In Colombia, there are few reports on the prevalence of blood parasites in tyraniid birds (Renjifo et al. 1952, Bennett \& Borrero 1976, Rodríguez \& Matta 2001).

Surveys to determine the haematozoan fauna of bird communities are useful to identify the various parasites that occur within a given geographical or ecological unit. In this study several species of the new world family Tyrannidae were studied in three localities with different ecological conditions. Based on the differences among regions and families suggested by White et al. (1978), the flycatchers occupy an interesting niche. First, the group has a neotropical origin (Bennett et al. 1980) and second, they seem to have a long established relationship with

Financial support: División de Investigación Bogotá, Universidad Nacional de Colombia

Corresponding author. Fax: +57-1-316.5310. E-mail: nemattac@unal.edu.co

Received 30 October 2003

Accepted 22 March 2004 parasites and vectors, which are native to South America (Bennett et al. 1991).

\section{MATERIALSAND METHODS}

Birds were collected from three sites in the Meta Department, eastern plains of Colombia (Figure) from June to August of 1999 and 2000; these periods are in the rainy season. The first site was located in the Villavicencio Botanical Gardens (VBG) (7339’ W; $\left.4^{\circ} 0.9^{\prime} \mathrm{N}\right)$ : at an elevation of $640 \mathrm{~m}$ above sea level, with a mean annual temperature of $26^{\circ} \mathrm{C}$ and an annual rainfall between 2500-3000 mm. The area is a secondary tropical rainforest and contains patches of trees of 20-30 m. The second site was in San Miguel; Fundación Yamato (71 $\left.31^{\prime} \mathrm{W} ; 4^{\circ} 31^{\prime} \mathrm{N}\right)$, at an elevation of $130 \mathrm{~m}$ above sea level, with an annual temperature of $28.7^{\circ} \mathrm{C}$ and annual rainfall of $2000 \mathrm{~mm}$. The vegetation is characterized by dry savanna and gallery forests. The third site was in Serranía de la Macarena (73 $57^{\prime}$ W; $3^{\circ} 18$ ' N) "El Cerrillo" Station. This natural area is protected by the National Natural Park system comprising the northeast limit of the Macarena. The area possesses great diversity of environments including gallery forests and savanna, at an elevation between 450-500 $\mathrm{m}$ above sea level, an annual mean temperature of $24^{\circ} \mathrm{C}$ and annual rainfall of $2973 \mathrm{~mm}$.

The birds were mist-netted. Three thin smears from each of the 159 birds collected were made from blood obtained from a clipped toenail. Smears were fixed in $100 \%$ methanol and stained with Giemsa stain ( $\mathrm{pH} \mathrm{7.2)} \mathrm{for} 40$ min. In order to determine the prevalence of haematozoa, each smear was scanned double blind under low magnification (X100) for $10 \mathrm{~min}$ for Leucocytozoon, Trypanosoma, and microfilariae and under oil immersion for $20 \mathrm{~min}$ for Plasmodium, Haemoproteus, and haemogregarines.

The intensity of infection with microfilariae and Plasmodium was established by counting 100 fields at a magnification of 1000 by moving the slide in areas where the blood cells formed a monolayer. A single monolayer field under x 100 oil objective contained approximately 100 cells (infected cell/10,000 erythrocytes) (Muñoz et al. 1999). 


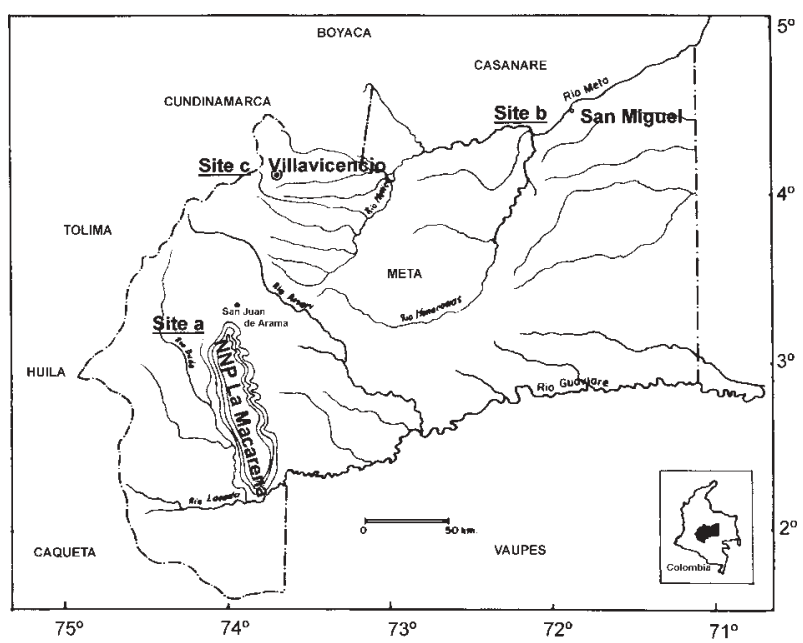

Study sites in the eastern plains of Colombia 1999-2000. Site a: NNP, La Macarena; Site b: San Miguel, Yamato; Site c: Villavicencio

\section{RESULTS}

A total of 159 flycatchers from three geographically diverse populations were examined for blood parasites (Table I); 16 individuals $(10.1 \%$ ) were infected with one or more haematozoa, the prevalence varies from $7 \%$ in Villavicencio to $11 \%$ in Macarena and Yamato. The most common parasites encountered were microfilariae, which occurred in nine birds (6\%), followed by Trypanosoma in six birds (4\%). Plasmodium occurred in only two birds $(1.3 \%)$. The following parasite infections in birds were recorded for the first time: Mionectes oleaginea - Plasmodium sp., and Trypanosoma sp.; Atalotriccus pilaris microfilariae, and Myiarchus cephalotes - Plasmodium sp. Trypomastigotes were detected in low numbers in three species of birds. Within three individuals of Mionectes oleaginea, only four or five trypomastigotes each were detected under exhaustive microscopic scanning. In Elaenia chiriquensis two trypomastigotes each were found and in Tyrannus melancholichus only one trypomastigote was detected. Morphometric data were obtained from 19 trypomastigotes (Table II). All of the trypomastigotes were small, body length $(\mathrm{BL}=20.12 \mu \mathrm{m}$ \pm 1.96 ) and very pleomorphic with a round, terminal kinetoplast staining intensely purple. The nucleus was oval, located about midbody and stained pink. Myonemes were not observed. Body width was the more variable characteristic $(6.6 \mu \mathrm{m} \pm 2.19)$, showing slender to broad morphs, but most trypomastigotes were broad. The trypomastigotes found were similar to Trypanosoma everetti Molyneux 1973 and resemble the small avian trypanosomes from South American birds described by other authors (Table II). In addition, they lacked the typical striated appearance of the T. avium s.l. group (Nandi \& Bennett 1994). Trypomastigotes of $T$. everetti, have been reported in several neotropical avian hosts, but this trypanosome species has not been registered previously in tyraniids (Bishop \& Bennett 1992).

One Plasmodium species, tentatively identified as Plasmodium relictum Grassi \& Feletti 1891, was present in the ochre-bellied flycatcher and the pale-edged flycatcher. One erythrocytic schizont, which displaced the host cell nucleus laterally, was seen in M. oleaginea and containing eight merozoites and one pigment granule. The gametocytes were spherical or subspherical, with 16-19 round black pigment granules usually aggregated in one or more foci. Microfilariae were found in low numbers in nine birds (Table I). Unfortunately, it was impossible to identify these on the basis of their morphological characteristics. A double infection with Trypanosoma and Plas-

TABLE I

Prevalence of hemoparasites in flycatchers from the eastern plains of Colombia

\begin{tabular}{|c|c|c|c|c|c|c|c|c|}
\hline \multirow[t]{2}{*}{ Species } & \multirow[t]{2}{*}{ Nr examined } & \multirow[t]{2}{*}{ Nr infected } & \multicolumn{3}{|c|}{ Locality } & \multicolumn{3}{|c|}{$\begin{array}{c}\text { Positive } \\
\text { individuals to parasite }\end{array}$} \\
\hline & & & $a$ & $b$ & $c$ & $T$ & M & $P$ \\
\hline Atalotriccus pilaris Pale-eyed pygmy-tyrant & 5 & 1 & 5 & & & & $1^{a}$ & \\
\hline Attila spadiceus Bright-rumped attila & 1 & 1 & 1 & & & & $1^{a}$ & \\
\hline Elaenia chiriquensis Lesser Elaenia & 12 & 2 & 3 & 7 & 2 & $2^{b}$ & & \\
\hline Elaenia parvirostris Small-billed Elaenia & 11 & 1 & 6 & 2 & 3 & & $1^{c}$ & \\
\hline Megarhynchus pitangua Boat-billed flycatcher & 7 & 1 & 2 & 5 & & & $1^{b}$ & \\
\hline Mionectes oleaginea ${ }^{d}$ Ochre-bellied flycatcher & 62 & 6 & 41 & & 21 & $3^{a}$ & $1^{a} 2^{b}$ & $1^{a}$ \\
\hline Myiarchus cephalotes Pale-edged flycatcher & 14 & 1 & 14 & & & & & $1^{a}$ \\
\hline Pitangus sulphuratus Great Kiskadee & 5 & 1 & 2 & & 3 & & $1^{a}$ & \\
\hline Tyrannus melancholichus Tropical Kingbird & 10 & 2 & 5 & 1 & 4 & $1^{a}$ & $1^{a}$ & \\
\hline Negative birds (see below) & 143 & & & & & & & \\
\hline Total & 159 & 16 & 91 & 26 & 42 & 6 & 9 & 2 \\
\hline$\%$ infected & & 10.1 & & & & 3.8 & 5.7 & 1.25 \\
\hline
\end{tabular}

T: Trypanosoma; M: microfilariae; P: Plasmodium; $a$ : "El Cerrillo" PNN Macarena; $b$ : San Miguel, Fundación Yamato; $c$ : Villavicencio (JBV); $d$ : double infection; negative birds (number examined in parentheses): Comptostoma obsoletum, Southern beardless tyrannulet (2); Elaenia flavogaster, Yellow-bellied Elaenia (2); Elaenia sp. (3); Empidomonus varius, Variegated flycatcher (2); Leptopogon amaurocephalus, Sepia-caped flycatcher (5); Myiarchus ferox, short-crested flycatcher (1); Myiopagis gaimardii, Forest Elaenia (1); Myiozetetes cayanensis, Rusty-margined flycatcher (7); Myiozetetes similis, Social flycatcher (1); Pharomins murina, Mouse-colored tyrannulet (2), Pitangus lictor, Lesser Kiskadee (4), Tolmomyias sulphurescens, Yellow-olive Flycatcher (1); Tyrannus tyrannus, Eastern Kingbird (1) 


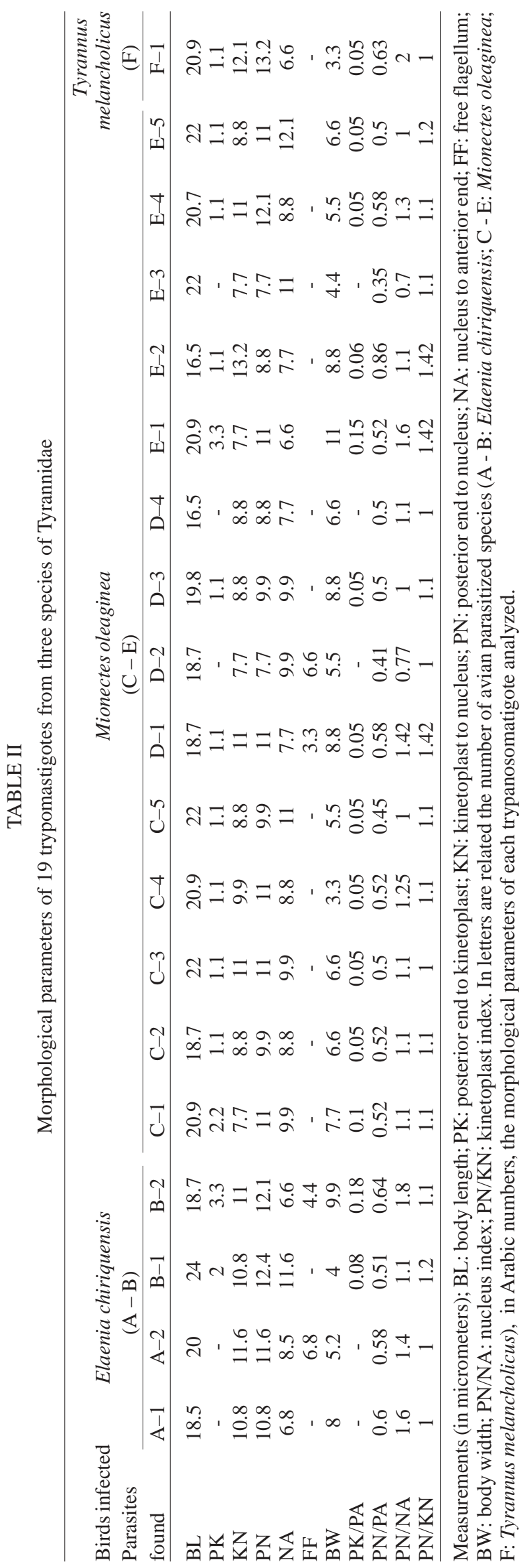

modium occurred in $M$. oleaginea, which was the most frequently sampled species in the survey. Additionally, this host presented the highest parasitaemia (2\%) with Plasmodium.

\section{DISCUSSION}

Even though flycatchers belong to a very diverse family, data on haematozoa from these hosts are fragmented and poorly understood (Table III). Our data indicate that flycatchers possess low hematozoan prevalence (10.1\%), which agrees with the hypothesis proposed by Bennett et al. (1980), that bird families with neotropical origin (i.e. Tyrannidae, Trochilidae) have a lower prevalence than those with Nearctic origin (i.e. Columbidae, Vireonidae). Furthermore, the low intensity of infections in our survey was also indicated by the low proportion of double infections (1/16), which is almost one-third part of double infections obtained for Greiner et al. (1975) in Nearctic birds. It suggests that some aspect of physiology or genetics of the flycatchers reduces the parasitism by haematozoa, in contrast to other families that have shown to be inherently more susceptible to blood parasites. It could also be interpreted as meaning that birds of this family have behavioral patterns (i.e. nesting sites, roosting sites, etc.) which reduce potential vector contact.

The high prevalence of microfilariae and Trypanosoma sp., representing $52.9 \%$ and $35.3 \%$ respectively of all of the infections, was the most striking aspect of this survey. These prevalences agree with those found for neotropical avian hosts (Bennett et al. 1991) suggesting that both vector composition and distribution in the Neotropical region differs from that in the rest of the world.

Previous reports of Trypanosoma have described a prevalence between $0.5 \%$ to $6 \%$ in peripheral blood (Table III). However, the true prevalence is likely to be higher in both prior studies and our study, because thin blood smears are not an ideal diagnostic procedure for the detection of Trypanosoma spp. (Bennett 1962). Culture and microhematocrit methods are more reliable methods for detection and identification of trypanosomes (Woo \& Bartlett 1982). Further, more studies on ornithophilic vectors are necessary to explain the high prevalence of microfilariae and Trypanosoma in the Neotropics.

Novyella is recorded as being the most frequently detected subgenus of Plasmodium in birds of the Neotropics (Gabaldón \& Ulloa 1976), but the only malaria parasites found in the present survey were identified as probably being $P$. (Haemamoeba) relictum. This species can cause severe mortality among colonies of Passer species and it is a cause of mortality in zoo birds (Garnham 1966). In neotropical flycatchers, $P$. relictum has been recorded in Megarhynchus pitangua, Pitangus sulphuratus, and Tyrannus melancholichus (Bennett et al.1982). However, to our knowledge, there are no studies on the specific pathogenic impact on flycatcher populations.

Apparently, avian species of Plasmodium have a much broader host spectrum compared to the host familial specificity of the genera Haemoproteus and Leucocytozoon, this could explain the paucity of the last genera in this study. The absence of Haemoproteus in this study is surprising, and might be due to limited sampling. Several 
TABLE III

Summary of surveys of haematozoa in flycatchers of America

\begin{tabular}{|c|c|c|c|c|c|c|c|c|c|c|}
\hline & \multirow{2}{*}{$\begin{array}{c}\mathrm{Nr} \text { of bird } \\
\text { examined }\end{array}$} & \multirow[b]{2}{*}{ Positive } & \multirow[b]{2}{*}{ Prevalence } & \multicolumn{6}{|c|}{ Prevalence } & \multirow[b]{2}{*}{ Reference } \\
\hline & & & & $H$ & $T$ & $\mathrm{~m}$ & $P$ & $L$ & $\mathrm{O}$ & \\
\hline Bolivia & 82 & 2 & 2.4 & & 1.2 & 1.2 & & & & Bennett et al. 1991 \\
\hline Brazil & 606 & 12 & 1.98 & 1.1 & 0.3 & 0.3 & & & 0.1 & Bennett \& Souza 1980 \\
\hline Colombia & 55 & 5 & 9.1 & 5.4 & & 1.8 & 1.8 & & & Bennett \& Borrero 1976 \\
\hline Jamaica & 103 & 4 & 3.9 & & 1.94 & & & & 0.9 & Bennett et al. 1980 \\
\hline Neotropics & 1242 & 120 & 9.7 & 6.5 & 0.9 & 1.6 & 1.2 & 0.2 & 0.2 & White et al. 1978 \\
\hline North America & a 306 & 72 & 23.5 & 4.2 & 8.2 & 7.2 & 2.0 & 4.9 & 0.7 & Greiner et al.1975 \\
\hline Panamá & 513 & 66 & 12.9 & 7.0 & 0.003 & 0.7 & 6.5 & & & Sousa \& Herman 1982 \\
\hline
\end{tabular}

H: Haemoproteus; T: Trypanosoma; m: microfilariae; P: Plasmodium; L: Leucocytozoon; O: others

surveys of Neotropical birds have shown that Tyraniids have prevalences of Haemoproteus between $0 \%$ and $7 \%$ (Table III). The reason for this distribution pattern could be associated with its restricted host specificity which reduces the possibilities of infecting a wide spectrum of hosts. Additionally, for the same area, previous studies showed that Haemoproteus infects other passeriform families, suggesting the presence of suitable ornithophilic vectors (Rodriguez \& Matta 2001).

Present findings on the haematozoan parasites collected in the three areas have shown that the prevalence varies from $7 \%$ in Villavicencio to $11 \%$ in Macarena and Yamato. Despite the fact that the prevalence values are similar to each other, these values could be correlated with the ecological conditions of the collection site. In addition, our results suggest that the transmission of the blood parasites occurs quite differently in the three locations. This is best illustrated by the transmission of Trypanosoma which was more frequently found in Macarena bird species, but not observed in the Villavicencio avian hosts. The biological differences could be attributed to the urban growth and the use of savanna and gallery forests for cattle ranches (i.e. Villavicencio), representing deteriorated and fragmented lands and a scarcity of natural habitats. Consequently both vector and avian host populations were impacted. Such differences might be due to sample size and host species sampled, rather than the result of simple geographical distance.

Some of the blood parasites found were similar to those previously described in other zoogeographic regions. However, it is important to note that both avian hosts and possibly vectors are different species or even different genera, than those originally described. This suggests the possibility that neotropical conditions may have developed new species of blood parasites adapted to the local hosts and vectors. For this reason a careful analysis of the biology of both vertebrate and invertebrate hosts, parasite life cycles, and cross-infections experiments are needed.

\section{ACKNOWLEDGEMENTS}

To J Celis and his staff of National Natural Park System, to J Ramirez of Estación Biológica Tropical Roberto Franco, and to B Takemoto of Fundación Yamato for permission to work in the area. To CJ Marinkelle, FG Stiles, and R Adlard for their professional assistance.

\section{REFERENCES}

Bennett GF 1962. The haematocrit centrifuge for the laboratory diagnosis of Haematozoa. Can J Zool 40: 124-125.

Bennett GF, Borrero JI 1976. Blood parasites of some birds from Colombia. J Wildl Dis 12: 454-458.

Bennett GF, Garvin M, Bates JM 1991. Avian haematozoa from west-central Bolivia. J Parasitol 77: 207-211.

Bennett GF, Witt H, White EM 1980. Blood parasites of some Jamaican birds. J Wildl Dis 16: 29-38.

Bennett GF, Whiteway M, Woodworth-Lynas C 1982. A Hostparasite Catalogue of the Avian Haematozoa, Occasional Papers in Biology 5, St John's, Memorial University of Newfoundland, Newfoundland.

Bishop MA, Bennett GF 1992. Host-parasite Catalogue of the Avian Haematozoa, Occasional Papers in Biology, Memorial University of Newfoundland, Newfoundland.

Gabaldón A, Ulloa G 1976. Encuesta sobre malaria aviaria en Venezuela: resultados del tercer y último año. Bol Dir Malar San Aml XVI:107-117.

Garnham PC 1966. Malaria Parasites and Other Haemosporidia, Blackwell Scientific Publications, Oxford.

Greiner EC, Bennett GF, White EM, Coombs RF 1975. Distribution of the avian hematozoa of North America. Can J Zool 53: 762-1787.

Haffer J 1985. Avian zoogeography of the Neotropical lowlands. In PA Buckley, MS Foster, ES Morton, RS Ridgely, FG Buckley (eds), Neotropical Ornithology, Ornithological Monographs 36, p. 113-196.

Muñoz E, Ferrer D, Molina R, Adlard RD 1999. Prevalence of haematozoa in birds of prey in Catalonia. Vet Record 144: 623-636.

Nandi NC, Bennett GF 1994. Re-description of Trypanosoma corvi Stephens and Christophers, 1908 emend. Baker, 1976 and remarks on the trypanosomes of the avian family Corvidae. Mem Inst Oswaldo Cruz 89: 145-151.

Renjifo S, Sanmartin C, Zulueta J 1952. A survey of the blood parasites of vertebrates in eastern Colombia. Acta Trop 9: 151-169.

Rodríguez OA, Matta NE 2001. Blood parasites in some birds from eastern plains of Colombia. Mem Inst Oswaldo Cruz 96: 173-1176.

White EM, Greiner EC, Bennett GF, Herman CM 1978. Distribution of the hematozoa of Neotropical birds. Rev Biol Trop 26: 43-102.

Woo PT, Bartlett CM 1982. Trypanosoma ontarioensis n.sp. and T. paddae from Corvus brachyrhynchos brachyrhynchos in Ontario, Canada, with notes on the biology of T. ontarioensis n.sp. Can J Zool 60: 2107-2115. 